\title{
Acid mine water neutralisation with ammonium hydroxide and desalination with barium hydroxide
}

\author{
MD Maila', JP Maree ${ }^{2}$ and LM Cele' \\ 'Department of Chemistry, Tshwane University of Technology, Private Bag X680, Pretoria, 0001, South Africa \\ ${ }^{2}$ Department of Environmental, Water and Earth Sciences, Tshwane University of Technology, Private Bag X680, Pretoria, 0001, South Africa
}

\begin{abstract}
In South Africa, acid mine drainage is polluting increasingly scarce ground- and surface water. The ammonium-barium (NB) process described in this paper consists of neutralisation and metal removal with $\mathrm{NH}_{4} \mathrm{OH}$, sulphate removal with $\mathrm{Ba}(\mathrm{OH})_{2}$ and $\mathrm{Ca}$ removal with $\mathrm{CO}_{2}$. Laboratory studies showed that metals are removed to low levels. This includes $\mathrm{Fe}(\mathrm{II})$, the predominant metal in mine water. It is first oxidised to $\mathrm{Fe}(\mathrm{III})$, whereafter it precipitates as $\mathrm{Fe}(\mathrm{OH})_{3}$. Sulphate is removed to low concentrations as $\mathrm{BaSO}_{4}$. During $\mathrm{CO}_{2}$ dosing, $\mathrm{CaCO}_{3}$ is precipitated to its saturation level. The simulation predictions followed the same pattern as the experimental results obtained. This study showed that $\mathrm{NH}_{4} \mathrm{OH}$ can be used for treatment of acid mine drainage rich in sulphates and $\mathrm{NH}_{4} \mathrm{OH}$ can be recycled in the process. Hydrated lime treatment resulted in removal of the remaining ammonia using a rotary evaporator.
\end{abstract}

Keywords: acid mine water, ammonium hydroxide, barium hydroxide, sulphate removal

\section{INTRODUCTION}

Acidic mine waters are continuously discharged from certain mines to the environment, with little treatment. Acid mine water contains high levels of $\mathrm{SO}_{4}$ in addition to $\mathrm{Fe}, \mathrm{Al}, \mathrm{Mn}$ and other metals. Coal mining and fertiliser manufacturing are examples of industrial operations that give rise to severe acid pollution (Maree et al., 2004). Clean water is essential for agriculture, domestic and industrial use, and increases in population have led to an increase in the water demand. South Africa (SA) is an arid country, which has exacerbated the problem. It has been predicted that the country's freshwater resources will be fully utilised within the next 20 to 30 years if the current growth in water demand and use (or abuse) is not altered (Van Niekerk and Maree, 2001). In the Western Basin of the Witwatersrand, Gauteng Province, mine water started to decant in 2002. In the Eastern Basin, a single pump station at Grootvlei Mine pumped out between 75 and $108 \mathrm{M} /$ day of mine-water. The pH can be as low as 2 (Jiménez et al., 2009) and poses a problem because the majority of natural life is adapted to survive at around $\mathrm{pH} 7$. About $540 \mathrm{Ml} / \mathrm{d}$ of acid mine water is produced in the Gauteng region alone (Hlabela, 2009).

AMD is formed when pyrite in contact with atmospheric oxygen becomes oxidised to soluble iron and sulphuric acid, frequently catalysed by sulphur-oxidising bacteria (Jennings et al., 2008).

$$
2 \mathrm{FeS}_{2}+7 \mathrm{O}_{2}+2 \mathrm{H}_{2} \mathrm{O} \rightarrow 2 \mathrm{Fe}^{2+}+4 \mathrm{H}^{+}+4 \mathrm{SO}_{4}^{2-}
$$

Mine-water treatment requires pre-treatment for neutralisation and metal removal, followed by desalination for removal of dissolved salts. The integrated limestone and lime process

\footnotetext{
To whom all correspondence should be addressed.

iㅛ +27 12382 6315; fax: +27 866425592 ;

e-mail: mavis.dineo@gmail.com

Received 30 May 2013; accepted in revised form 20 June 2014.
}

was developed for neutralisation and partial $\mathrm{SO}_{4}$ removal from AMD (Maree, 2003). Limestone and lime are used to increase the $\mathrm{pH}$ and, together with aeration, $\mathrm{Fe}(\mathrm{II})$ is oxidised and precipitates as $\mathrm{Fe}(\mathrm{OH})_{3}$. Limestone is used for initial AMD treatment as it is less costly than lime. It is moreover safe to handle and its dissolution occurs at $\mathrm{pH}$ below 7, obviating the need for $\mathrm{pH}$ control. In the second stage, lime is introduced to precipitate the remaining metals such as $\mathrm{Mn}$ and $\mathrm{Al}$. Unfortunately, its successful application is limited as it only lowers $\mathrm{SO}_{4}$ concentration to around $1200 \mathrm{mg} / \ell$ (INAP, 2000). Other treatment techniques have been developed that utilise limestone, which can neutralise acid but does not raise the $\mathrm{pH}$ sufficiently to remove metals (Ziemkiewicz et al., 1997). Several other processes can be considered for sulphate removal, e.g., biological sulphate removal, SAVMIN (by ettringite formation), and membrane processes. Barium sulphate is highly insoluble which makes $\mathrm{Ba}$ dosing suitable for removal of $\mathrm{SO}_{4}$.

$\mathrm{BaCO}_{3}$ can be used for $\mathrm{SO}_{4}$ removal according to the following reaction:

$$
\mathrm{BaCO}_{3}+\mathrm{CaSO}_{4} \rightarrow \mathrm{BaSO}_{4}+\mathrm{CaCO}_{3}
$$

Trusler et al. (1988) developed a $\mathrm{BaCO}_{3}$ method for $\mathrm{SO}_{4}$ removal by using a two-stage fluidised-bed reactor system to overcome the other problems identified by Kun (1972), i.e. long retention times and the high $\mathrm{Ba}$ concentrations in the treated water. $\mathrm{BaCO}_{3}$ and lime would be added to the effluent to soften the water and produce a precipitate. The disadvantage of Reaction (2) is that $\mathrm{BaSO}_{4}$ and $\mathrm{CaCO}_{3}$ co-precipitate. Maree et al. (1989) noted a problem in separating co-precipitated $\mathrm{BaSO}_{4}$ and $\mathrm{CaCO}_{3}$. However, the $\mathrm{BaCO}_{3}$ became inactive when coated with precipitated metal hydroxide, which made it unsuitable for most mine waters. Alternatively, $\mathrm{Ba}(\mathrm{OH})_{2}$ can be used in place of $\mathrm{BaCO}_{3}$ and offers the benefits of rapid reaction times and precipitation of only $\mathrm{BaSO}_{4}$.

The purpose of this investigation was to demonstrate that $\mathrm{NH}_{4} \mathrm{OH}$ in combination with $\mathrm{Ba}(\mathrm{OH})_{2}$ and lime treatment offers an attractive solution for treatment of acid mine-water 


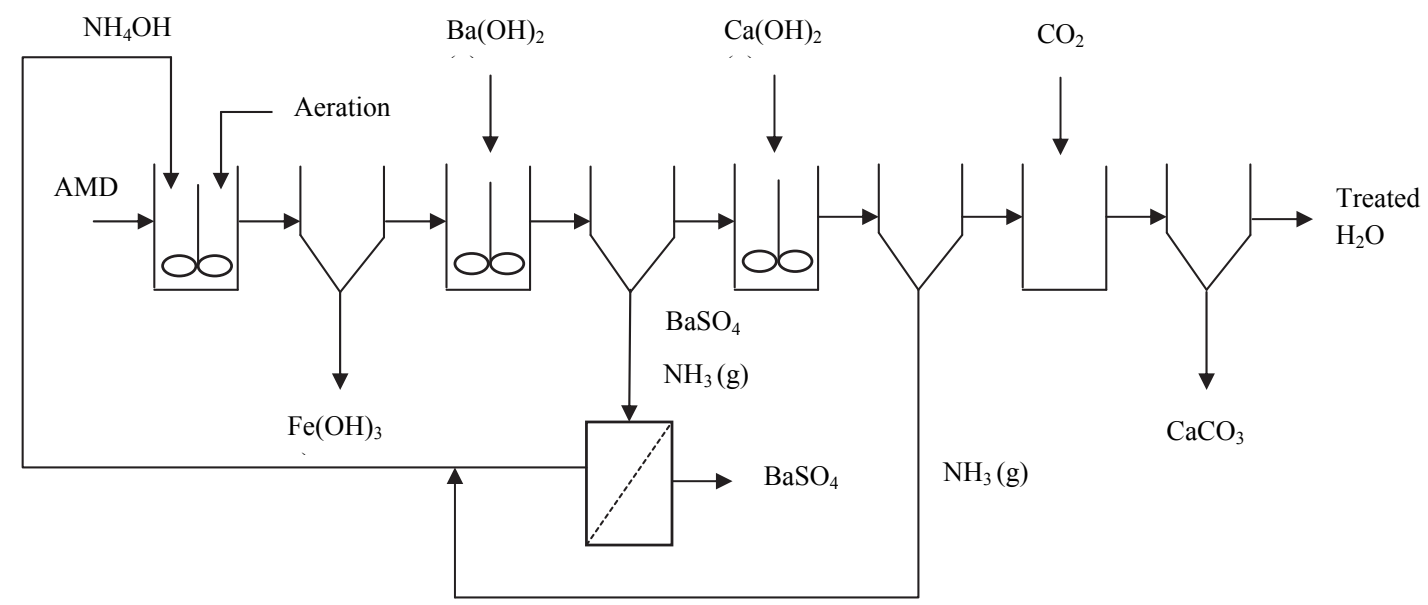

Figure 1

Process flow-diagram of integrated $\mathrm{NH}_{4} \mathrm{OH} / \mathrm{Ba}(\mathrm{OH})_{2}$ /lime process for acid mine water treatment

rich in $\mathrm{Fe}(\mathrm{II})$. In this approach, $\mathrm{Fe}(\mathrm{II})$ is oxidised and precipitated in the presence of added $\mathrm{NH}_{4} \mathrm{OH}$ as $\mathrm{Fe}(\mathrm{OH})_{3}$, allowing the precipitated $\mathrm{Fe}(\mathrm{OH})_{3}$ to be separated. In the following stage, $\mathrm{SO}_{4}$ is precipitated with $\mathrm{Ba}(\mathrm{OH})_{2}$, as $\mathrm{BaSO}_{4}$, and separated as a sludge. $\mathrm{NH}_{3}$ is partially stripped off because of the increased $\mathrm{pH}$ when $\mathrm{Ba}(\mathrm{OH})_{2}$ is dosed. Next, lime is added to increase the $\mathrm{pH}$ to above 12.4, to allow stripping off of the remaining $\mathrm{NH}_{3}$. Calcium is recovered as $\mathrm{CaCO}_{3}$ by introducing $\mathrm{CO}_{2}$ into the solution.

The overall objectives of the study were the following:

- Identify optimum conditions for Fe(II) oxidation when using $\mathrm{NH}_{4} \mathrm{OH}$ as alkali

- Determine optimum conditions for removal of $\mathrm{SO}_{4}$ when $\mathrm{Ba}(\mathrm{OH})_{2}$ is added for precipitation of $\mathrm{BaSO}_{4}$ (barite)

- Demonstrate that limestone can be used for free acid removal

- Identify optimum conditions for recovery of $\mathrm{NH}_{4} \mathrm{OH}$

- Identify optimum conditions for removal of calcium by introduction of $\mathrm{CO}_{2}$

- Compare the behaviour of simulated and real acid mine water

- Compare actual measured water quality with that predicted by Visual MINTEQ software

\section{EXPERIMENTAL}

\section{Feedstock}

Mine water from the decanting site in Randfontein was used as feed water containing $\mathrm{Fe}(\mathrm{II})(670 \mathrm{mg} / \ell)$ and $\mathrm{SO}_{4}(2090$ $\mathrm{mg} / \ell$ ). Simulated AMD was prepared from an aqueous mixture of $\mathrm{FeSO}_{4}$ (Rochelle Chemicals, Pretoria) and $\mathrm{H}_{2} \mathrm{SO}_{4}(\mathrm{SMM}$ Instruments, Johannesburg). Simulated mine-water was prepared as follows: $\mathrm{FeSO}_{4} \cdot 7 \mathrm{H}_{2} \mathrm{O}(1.50 \mathrm{~g})$ and concentrated $\mathrm{H}_{2} \mathrm{SO}_{4}$ $(11.0 \mathrm{ml})$ were each dissolved together in distilled water and made up to $500 \mathrm{~m} \ell$ solution containing $600 \mathrm{mg} / \ell$ of $\mathrm{Fe}(\mathrm{II})$ and $2063 \mathrm{mg} / \ell$ of $\mathrm{SO}_{4}$.

\section{Reagents}

Aqueous $\mathrm{NH}_{3}$ (SMM Instruments, Johannesburg) was used for neutralisation. Compressed air (Afrox, Pretoria) was bubbled into the reactor at a controlled flow-rate to provide the oxygen for iron oxidation. $\mathrm{Ba}(\mathrm{OH})_{2}$ (Merck, $\mathrm{SA}$ ) was used for $\mathrm{SO}_{4}$ removal. Lime (Rochelle Chemicals, Pretoria) was used for removing the remaining $\mathrm{NH}_{3}$ in the solution and $\mathrm{CO}_{2}$ (Afrox, Pretoria) was used for the precipitation of $\mathrm{Ca}$ as $\mathrm{CaCO}_{3} \cdot \mathrm{CaCO}_{3}$ (Rochelle Chemicals, Pretoria) was used to remove free acid in the alternative method.

\section{Equipment}

Neutralisation of acidic mine water with $\mathrm{NH}_{4} \mathrm{OH}$ and $\mathrm{SO}_{4}$ removal with $\mathrm{Ba}(\mathrm{OH})_{2}$ was studied using arrays of stirred beakers. $\mathrm{NH}_{3}$ stripping studies were done using a desorption column and a rotary evaporator. The desorption column was a cylinder (diameter: $223 \mathrm{~mm}$; height: $2000 \mathrm{~mm}$ ), packed with plastic rings that served to increase the surface area, and fitted with a pump that circulated the sample. A spray nozzle on top of the column distributed the sample evenly across the cross section of the column. In this column $\mathrm{NH}_{3}$ (aq) diffuses as $\mathrm{NH}_{3}$ gas. A rotary evaporator was used as an alternative method for removal of $\mathrm{NH}_{3}$.

\section{Experimental procedures}

Batch studies were carried out using $5 \ell$ and $500 \mathrm{~m} \ell$ stirred, glass beakers. Compressed air was passed through the solutions using sintered glass diffusers at different flow-rates. Simulated mine water and $\mathrm{NH}_{4} \mathrm{OH}$ were mixed at Time Zero. $\mathrm{NH}_{4} \mathrm{OH}$ was added slowly to the solution at $10 \mathrm{~m} \ell$ intervals and $10 \mathrm{~min}$ was allowed at each interval for equilibration. Compressed air was passed through the reaction mixture. Samples were taken at regular intervals and assayed for $\mathrm{pH}$ and $\mathrm{Fe}(\mathrm{II})$ concentration using redox titration.

$\mathrm{SO}_{4}$ was removed as precipitated $\mathrm{BaSO}_{4}$ by addition of $\mathrm{Ba}(\mathrm{OH})_{2}$. $\mathrm{NH}_{3}$ was removed in 2 stages: $\mathrm{Ba}(\mathrm{OH})_{2}$ was used in the first stage for partial removal and in the second stage lime was added into the solution, fed into the column by a pump and recycled under room temperature for $3 \mathrm{~h}$. Compressed air removed $\mathrm{NH}_{3}$ as $\mathrm{NH}_{3}$ gas. The remaining sample was taken at intervals and assayed for $\mathrm{pH}$ and $\mathrm{NH}_{3}$ concentration. $\mathrm{NH}_{3}$ gas was not adsorbed to any surface; hence further experiments to investigate adsorbtion to an acidic solution are planned.

The previous method needs hydrated lime to remove the remaining $\mathrm{NH}_{3}$ from the solution. The costs can be minimised 
by addition of limestone in the first stage of the process. In this experiment, $\mathrm{CaCO}_{3}$ was added to remove free acid so that $\mathrm{NH}_{4} \mathrm{OH}$ only removes metal hydroxides. In this process, addition of hydrated lime for $\mathrm{NH}_{3}$ removal was eliminated.

\section{Experimental programme}

The effects of the following parameters on the Fe (II) oxidation were determined:

- Air flow-rates $(3.1,5,5.6,7.9 \mathrm{l} / \mathrm{min})$

- $\mathrm{NH}_{3}$ /acidity (mol ratios of $0.2,0.4,0.6,0.8,1.0,1.2,1.4,1.6$ )

- Temperature $\left(25,35,45,65^{\circ} \mathrm{C}\right)$

Batch studies were carried out to demonstrate the removal of $\mathrm{SO}_{4}$ in the solution with addition of $\mathrm{Ba}(\mathrm{OH})_{2}$ by varying the

$\mathrm{SO}_{4} \mathrm{removed} / \mathrm{Ba}$ dosed $\mathrm{mol}$ ratio ( $\mathrm{mol} / \mathrm{mol}: 0.5,1,1.5$ ).

The effects of the following parameters on the $\mathrm{NH}_{3}$ stripping were determined:

- Air bubbled through to the desorption column $(119,145$, $168 \mathrm{l} / \mathrm{min})$

- Amount of packing material in the desorption column (empty, half-full and fully- packed)

- Temperature in the rotary evaporator for removal of $\mathrm{NH}_{3}$ as a gas in the solution $\left(25,35,45,55^{\circ} \mathrm{C}\right)$

\section{ANALYTICAL}

Water samples were collected at various stages, filtered (Whatman $0.45 \mu \mathrm{m}$ filter paper) and assayed for $\mathrm{Fe}(\mathrm{II}), \mathrm{pH}$, $\mathrm{NH}_{3}, \mathrm{Ca}, \mathrm{SO}_{4}$ and alkalinity concentrations using standard procedures (APHA, 2012; Vogel, 1989). $\mathrm{NH}_{3}$ analyses were done using BÜCHI Distillation Unit B-324. Metals were assayed using atomic absorption spectroscopy.

$\mathrm{Fe}(\mathrm{II})$ concentrations were determined by adding filtered sample $(10 \mathrm{~m} \ell), 1 \mathrm{~N} \mathrm{H}_{2} \mathrm{SO}_{4}(10 \mathrm{~m} \ell)$ and Zimmerman-Reinhard reagent $(10 \mathrm{~m} \ell)$ to an Erlenmeyer flask $(100 \mathrm{~m} \ell)$ and titrating the solution with $0.1 \mathrm{~N} \mathrm{KMnO}_{4}$ until pale pink (Vogel, 1989). $\mathrm{NH}_{3}$ was determined by distillation, where $100 \mathrm{m \ell}$ of sample was placed in a distillation flask and adjusted to $\mathrm{pH} 12.4$ with addition of $\mathrm{Ba}(\mathrm{OH})_{2} \cdot 8 \mathrm{H}_{2} \mathrm{O}$. Indicator boric acid solution was used as absorbent for the $\mathrm{NH}_{3}$ distillate (APHA, 2012).

Calcium was determined as total hardness because magnesium was not present. Filtered sample $(5 \mathrm{~m} \ell)$, water $(45 \mathrm{ml})$, dilute $\mathrm{NH}_{4}$ and Eriochrome Black T indicator were added to an
Erlenmeyer flask $(100 \mathrm{~m} \mathrm{l})$. The solution was titrated with 0.02 M EDTA to colour change (APHA, 2012). $\mathrm{SO}_{4}$ was determined by adding filtered sample $(2 \mathrm{m \ell})$ and conditioning reagent $(2 \mathrm{~m} \ell)$ to a volumetric flask $(50 \mathrm{~m} \ell)$ made up to volume with distilled water. A $20 \mathrm{~m} \ell$ aliquot of the solution was mixed with $0.15 \mathrm{~g}$ of $\mathrm{BaCl}_{2}$ in the cuvette and the turbidity was measured using a turbidity meter (Vogel, 1989).

Alkalinity was determined by titration of sample $(5 \mathrm{ml})$ to pH 4.3 using $0.1 \mathrm{~N} \mathrm{HCl}$ (APHA, 2012). Ca, Ni, Co, Zn, K and $\mathrm{Mn}$ were assayed using atomic absorption spectrophotometry (APHA, 2012).

\section{RESULTS AND DISCUSSION}

\section{Water quality}

\section{Comparison between real and simulated acid mine water}

Tables 1 and 2 show the chemical compositions of the water after various treatment stages for simulated and real acid mine water, respectively. $\mathrm{Fe}(\mathrm{II})$ concentrations were lowered to $<10 \mathrm{mg} / \mathrm{l}$ in both cases, after addition of $\mathrm{NH}_{4} \mathrm{OH}$. $\mathrm{SO}_{4}$ concentrations after $\mathrm{Ba}(\mathrm{OH})_{2}$ addition were $<400 \mathrm{mg} / \ell$. In real acid mine-water, the initial $\mathrm{pH}$ was 4.2 and less free acid was present. $\mathrm{Ba}(\mathrm{OH})_{2}$ was added to raise the $\mathrm{pH}$ to 11.9. This made addition of lime unnecessary for removal of $\mathrm{NH}_{3}$.

\section{Chemical reactions for simulated acid mine water}

In the ammonium-barium (NB) process, a variation of the $\mathrm{MBO}$ (magnesium barium oxide) process (Bologo et al., 2011), $\mathrm{Mg}(\mathrm{OH})_{2}$ was replaced with $\mathrm{NH}_{4} \mathrm{OH}$. During $\mathrm{NH}_{4} \mathrm{OH}$ treatment, acid and the metals assayed for were reduced to below the maximum permissible limit according to the general standard. The lowering of the metals in the case of $\mathrm{NH}_{4} \mathrm{OH}$ treatment was mainly due to the oxidation of $\mathrm{Fe}^{2+}$ to $\mathrm{Fe}^{3+}$ (Reaction (3)) and precipitation as $\mathrm{Fe}(\mathrm{OH})_{3}$ (Reaction (4)). This was owing to the low solubility-product for $\mathrm{Fe}(\mathrm{OH})_{3}\left(K_{s p}=2.64 \times 10^{-39}\right)$. $\mathrm{NH}_{4} \mathrm{OH}$ neutralises the acid produced and forms $\mathrm{NH}_{4}^{+}$ions (Reaction (5)). $\mathrm{NH}_{3}$ concentration was lowered from $1020 \mathrm{mg} / \ell$ to 425 $\mathrm{mg} / \ell$ by dosing $\mathrm{Ba}(\mathrm{OH})_{2} \cdot 8 \mathrm{H}_{2} \mathrm{O}$ (Reaction (6)) and simultaneously lowering $\mathrm{SO}_{4}$ concentration from $1786 \mathrm{mg} / \ell$ to $350 \mathrm{mg} / \ell$ (Reaction (6)). Lime was added to lower the remaining $\mathrm{NH}_{3}$ concentration to $8.5 \mathrm{mg} / \ell$ by stripping using rotary evaporator

\begin{tabular}{|c|c|c|c|c|c|}
\hline \multicolumn{6}{|c|}{$\begin{array}{c}\text { TABLE } 1 \\
\text { Chemical composition of feed and treated simulated acid mine water which was treated with } \mathrm{NH}_{4} \mathrm{OH} \text {, } \\
\mathrm{Ba}(\mathrm{OH})_{2} \text { and lime }\end{array}$} \\
\hline \multirow[t]{3}{*}{ Parameter } & \multicolumn{5}{|c|}{ Chemical composition } \\
\hline & \multirow[t]{2}{*}{ Feed } & \multicolumn{4}{|c|}{ Treated } \\
\hline & & $\mathrm{NH}_{4} \mathrm{OH}$ & $\mathrm{Ba}(\mathrm{OH})_{2}$ & $\mathrm{Ca}(\mathrm{OH})_{2}$ & $\mathrm{CO}_{2}$ \\
\hline Dosage (mmol) & - & 73 & 14.4 & 15.0 & - \\
\hline $\mathrm{NH}_{3} /$ Acidity $(\mathrm{mol} / \mathrm{mol})$ & & 1.2 & & & \\
\hline $\mathrm{Ba}$ dosage $/ \mathrm{SO}_{4}$ removed $(\mathrm{mol} / \mathrm{mol})$ & & & 0.96 & & \\
\hline \multicolumn{6}{|l|}{ Water quality (mmol where applicable) } \\
\hline $\mathrm{pH}$ & 1.9 & 9.9 & 10.6 & 12.6 & 6.5 \\
\hline Acidity $\left(\mathrm{mmol} \mathrm{CaCO}_{3}\right)$ & 21.5 & N/A & N/A & N/A & N/A \\
\hline $\mathrm{Fe}(\mathrm{II})$ & 10.74 & 0.15 & 0.148 & 0.146 & 0.143 \\
\hline $\mathrm{SO}_{4}$ & 21.49 & 18.6 & 3.66 & 3.63 & 3.57 \\
\hline $\mathrm{NH}_{3}$ & $\mathrm{~N} / \mathrm{A}$ & 60 & 25 & 5 & 0.48 \\
\hline
\end{tabular}

N/A: not assayed 


\begin{tabular}{|c|c|c|c|c|}
\hline \multicolumn{5}{|c|}{$\begin{array}{c}\text { TABLE } 2 \\
\text { Chemical composition of feed and treated authentic acid mine-water when treated with } \mathrm{NH}_{4} \mathrm{OH} \text { and } \\
\mathrm{Ba}(\mathrm{OH})_{2}\end{array}$} \\
\hline \multirow[t]{3}{*}{ Parameter } & \multicolumn{4}{|c|}{ Chemical composition } \\
\hline & \multirow[t]{2}{*}{ Feed } & \multicolumn{3}{|c|}{ Treated } \\
\hline & & $\mathrm{NH}_{4} \mathrm{OH}$ & $\mathrm{Ba}(\mathrm{OH})_{2}$ & $\mathrm{CO}_{2}$ \\
\hline Dosage (mmol) & - & 73.0 & 14.4 & N/A \\
\hline $\mathrm{NH}_{3} /$ acidity $(\mathrm{mol} / \mathrm{mol})$ & & 1.2 & & \\
\hline Ba dosage $/ \mathrm{SO}_{4}$ removed $(\mathrm{mol} / \mathrm{mol})$ & & & 0.83 & \\
\hline \multicolumn{5}{|l|}{ Water quality (mmol where applicable) } \\
\hline $\mathrm{pH}$ & 3.8 & 9.6 & 11.2 & 6.8 \\
\hline Acidity $\left(\mathrm{mmol} \mathrm{CaCO}_{3}\right)$ & 8.50 & $\mathrm{~N} / \mathrm{A}$ & $\mathrm{N} / \mathrm{A}$ & $\mathrm{N} / \mathrm{A}$ \\
\hline $\mathrm{Fe}$ & 12.0 & 0.016 & 0.002 & $<\mathrm{DL}$ \\
\hline $\mathrm{Mn}$ & 1.16 & 0.036 & $<\mathrm{DL}$ & $<\mathrm{DL}$ \\
\hline Co & 0.34 & 0.0043 & $<\mathrm{DL}$ & $<\mathrm{DL}$ \\
\hline $\mathrm{Mg}$ & 13.3 & 16.83 & 5.54 & $<\mathrm{DL}$ \\
\hline $\mathrm{Ca}$ & 10.5 & 10.0 & 5.5 & $<\mathrm{DL}$ \\
\hline $\mathrm{Zn}$ & 0.0017 & $<\mathrm{DL}$ & $<\mathrm{DL}$ & $<\mathrm{DL}$ \\
\hline $\mathrm{Ni}$ & 0.017 & $<\mathrm{DL}$ & $<\mathrm{DL}$ & $<\mathrm{DL}$ \\
\hline $\mathrm{Cl}$ & 20.57 & 15.796 & 15.4 & 7.90 \\
\hline $\mathrm{K}$ & 0.11 & 0.053 & 0.095 & $<\mathrm{DL}$ \\
\hline $\mathrm{SO}_{4}$ & 23.1 & 21.6 & 4.97 & N/A \\
\hline $\mathrm{NH}_{3}$ & $\mathrm{~N} / \mathrm{A}$ & 51.94 & 0.47 & N/A \\
\hline
\end{tabular}

N/A: not assayed

$<D L$ : below detection limit

(Reaction (7)). Calcium was recovered by dosing $\mathrm{CO}_{2}$ (Reaction (8)). $\mathrm{NH}_{3}$ was partially stripped from the solution as $\mathrm{NH}_{3}$ gas after addition of $\mathrm{Ba}(\mathrm{OH})_{2}(\mathrm{pH} 10.6)$, as $\mathrm{NH}_{3}$ becomes sufficiently volatile only at $\mathrm{pH}>12.4$; hence the need for lime addition to increase the $\mathrm{pH}$. Excess $\mathrm{Ba}(\mathrm{OH})_{2}$ was not added to increase the $\mathrm{pH}$ because excess $\mathrm{Ba}$ in the treated water must be avoided on account of its toxicity to humans and animals.

$$
\begin{aligned}
& 2 \mathrm{Fe}^{2+}+\frac{1}{2} \mathrm{O}_{2}+2 \mathrm{H}^{+}+3 \mathrm{SO}_{4}^{2-} \\
& \rightarrow 2 \mathrm{Fe}^{3+}+3 \mathrm{SO}_{4}^{2-}+\mathrm{H}_{2} \mathrm{O} \\
& 2 \mathrm{Fe}^{3+}+6 \mathrm{H}_{2} \mathrm{O} \rightarrow 2 \mathrm{Fe}(\mathrm{OH})_{3}+6 \mathrm{H}^{+} \\
& 6 \mathrm{H}^{+}+3 \mathrm{SO}_{4}^{2-}+6 \mathrm{NH}_{4} \mathrm{OH} \\
& \rightarrow 6 \mathrm{NH}_{4}^{+}+6 \mathrm{H}_{2} \mathrm{O}+3 \mathrm{SO}_{4}^{2-}
\end{aligned}
$$

$$
6 \mathrm{NH}_{4}^{+}+3 \mathrm{SO}_{4}^{2-}+3 \mathrm{Ba}(\mathrm{OH})_{2}
$$$$
\rightarrow 3 \mathrm{NH}_{4} \mathrm{OH}+3 \mathrm{NH}_{3}+3 \mathrm{BaSO}_{4}+3 \mathrm{H}_{2}
$$$$
3 \mathrm{NH}_{4} \mathrm{OH}+\mathrm{Ca}(\mathrm{OH})_{2} \rightarrow \mathrm{Ca}(\mathrm{OH})_{2}+3 \mathrm{H}_{2} \mathrm{O}+3 \mathrm{NH}_{3}
$$$$
\mathrm{Ca}(\mathrm{OH})_{2}+\mathrm{CO}_{2} \rightarrow \mathrm{CaCO}_{3}+\mathrm{H}_{2} \mathrm{O}
$$$$
2 \mathrm{Fe}^{2+}+2 \mathrm{H}^{+}+3 \mathrm{SO}_{4}^{2-}+\frac{1}{2} \mathrm{O}_{2}+6 \mathrm{NH}_{4} \mathrm{OH}
$$$$
+3 \mathrm{Ba}(\mathrm{OH})_{2}+\mathrm{Ca}(\mathrm{OH})_{2}+\mathrm{CO}_{2}
$$$$
\rightarrow 2 \mathrm{Fe}(\mathrm{OH})_{3}+3 \mathrm{BaSO}_{4}+6 \mathrm{NH}_{3}+\mathrm{CaCO}_{3}+8 \mathrm{H}_{2} \mathrm{O}
$$

\section{$\mathrm{Fe}$ (II)-oxidation in the presence of $\mathrm{NH}_{4} \mathrm{OH}$ for neutralisation}

The rate at which $\mathrm{Fe}(\mathrm{II})$ is oxidised depends on variable parameters, including $\mathrm{pH}$, concentration of dissolved $\mathrm{O}_{2}$ and

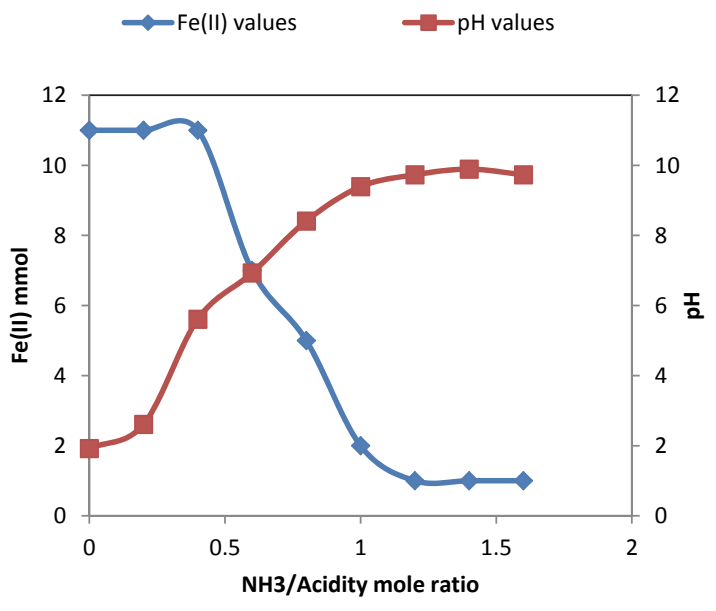

Figure 2

Effect of $\mathrm{NH}_{3}$ /acidity on the rate of Fe(II) removal by oxidation and precipitation (600 $\mathrm{mg} / \mathrm{l} \mathrm{Fe}(\mathrm{II}), 2150 \mathrm{mg} / \mathrm{l}$ acidity, $25^{\circ} \mathrm{C}$ )

temperature (Werner and Lee, 1961). Figure 2 shows that the presence of $\mathrm{NH}_{4} \mathrm{OH}$ in the acidic solution affects the oxidation of $\mathrm{Fe}(\mathrm{II})$. The mol ratio of $\mathrm{NH}_{3}$ to acidity was determined to establish how much $\mathrm{NH}_{3}$ was required to remove the free acid so as to remove Fe by raising the $\mathrm{pH}$.

The optimum $\mathrm{NH}_{3}$ /acidity mol ratio was 1.2 , because at that mol ratio the $\mathrm{pH}$ of the solution was above 9 and the $\mathrm{Fe}(\mathrm{II})$ concentration was $<10 \mathrm{mg} / \ell$. Figure 3 shows the effect of aeration rate on the oxidation rate of $\mathrm{Fe}$ (II). It was noted that the higher the flow-rate of aeration the faster the oxidation rate, although the effect was marginal. Due to the high solubility of $\left(\mathrm{NH}_{4}\right)_{2} \mathrm{SO}_{4}(74.4 \mathrm{~g} / 100 \mathrm{~m} \ell)$, co-precipitation of sulphates and metal hydroxides was avoided. 


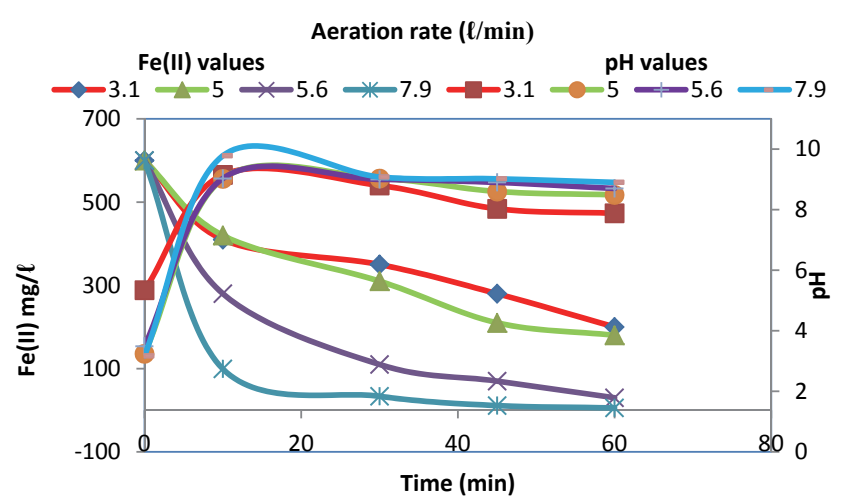

Figure 3

Effect of aeration-rate ( $\mathrm{\ell} / \mathrm{min})$ on the rate of Fe(II) oxidation $(600 \mathrm{mg} / \mathrm{\ell}$ $\mathrm{Fe}(\mathrm{II}), 2150 \mathrm{mg} / \mathrm{l}$ acidity; $876 \mathrm{mg} / \mathrm{N} \mathrm{NH}_{3^{\prime}} 25^{\circ} \mathrm{C}$ )

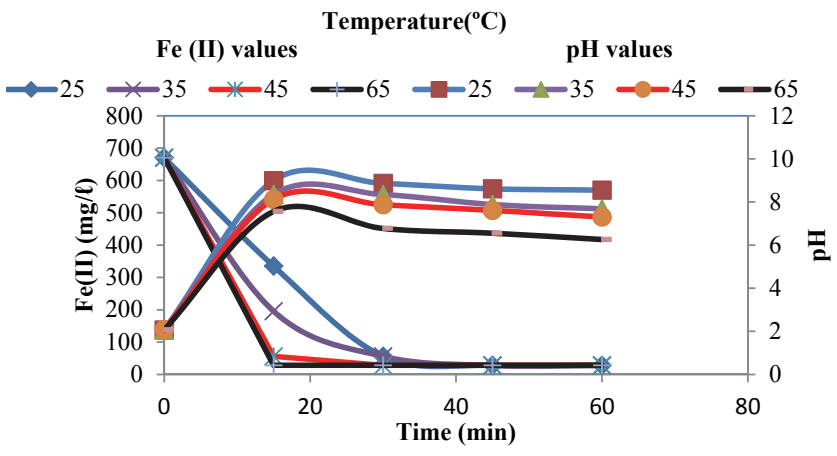

Figure 4

Effect of temperature on the rate of Fe(II) oxidation $(600 \mathrm{mg} / \mathrm{\ell} \mathrm{Fe}$ (II), $2150 \mathrm{mg} / \mathrm{\ell}$ acidity, $\left.876 \mathrm{mg} / \mathrm{l} \mathrm{NH}_{3}\right)$

Figure 4 shows the effects of temperature and the graphs showed, as expected, that an increment in temperature resulted in slightly faster $\mathrm{Fe}(\mathrm{II})$ oxidation. A problem was that the $\mathrm{pH}$ dropped due to $\mathrm{NH}_{3}$ stripping. Therefore, for optimum Fe(II) oxidation, it was carried out at room temperature.

\section{Sulphate and partial ammonia removal using barium hydroxide}

$\mathrm{Ba}(\mathrm{OH})_{2}$ was used for $\mathrm{SO}_{4}$ removal instead of lime because of the low solubility product of barite $\left(K_{s p}=1.08 \times 10^{-10}\right)$ compared to gypsum $\left(K_{s p}=4.93 \times 10^{-5}\right)$. Figure 5 shows experimental, theoretical and simulated results for optimum $\mathrm{Ba} / \mathrm{SO}_{4}$ mol ratio dosed. The pattern for the removal of $\mathrm{SO}_{4}$ was similar.

\section{Ammonia removal using hydrated lime}

The rate of $\mathrm{NH}_{3}$ desorption depends on the temperature, the height of the packed column and air flow rate (Orvos et al., 2010). Figure 6 shows the effect of air flow rate. It was noted that at the air flow rate of $168 \mathrm{l} / \mathrm{min}, \mathrm{NH}_{3}$ concentration was reduced from $525 \mathrm{mg} / \ell$ to $11.9 \mathrm{mg} / \ell$ and the $\mathrm{pH}$ was lowered from 13.4 to 9.0 due to $\mathrm{NH}_{3}$ gas being stripped out.

Figure 7 shows the effect of amounts of column packing material on $\mathrm{NH}_{3}$ removal. It was noted that the stripping of $\mathrm{NH}_{3}$ with a fully packed column proceeded at the fastest rate.

The effect of temperature on $\mathrm{NH}_{3}$ stripping using a rotary evaporator was determined. Figure 8 showed that, as expected, the higher the temperature the more $\mathrm{NH}_{3}$ becomes stripped out

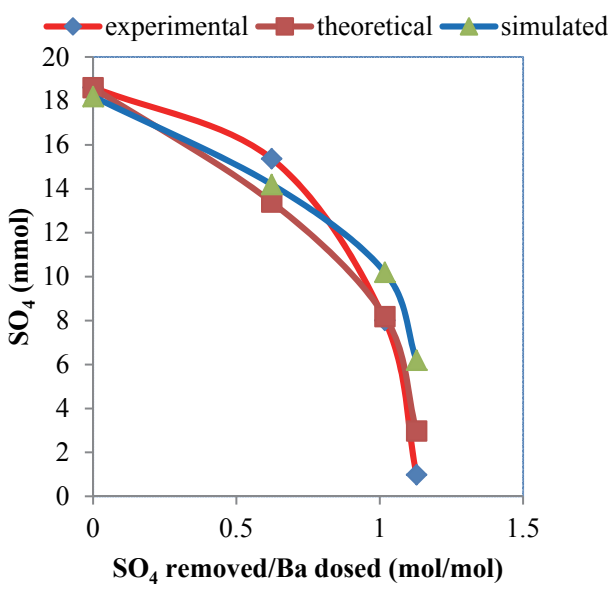

Figure 5

Comparison on the effect of $\mathrm{Ba} / \mathrm{SO}_{4}$ mol ratio dosed, on $\mathrm{SO}_{4}\left(25^{\circ} \mathrm{C}\right)$

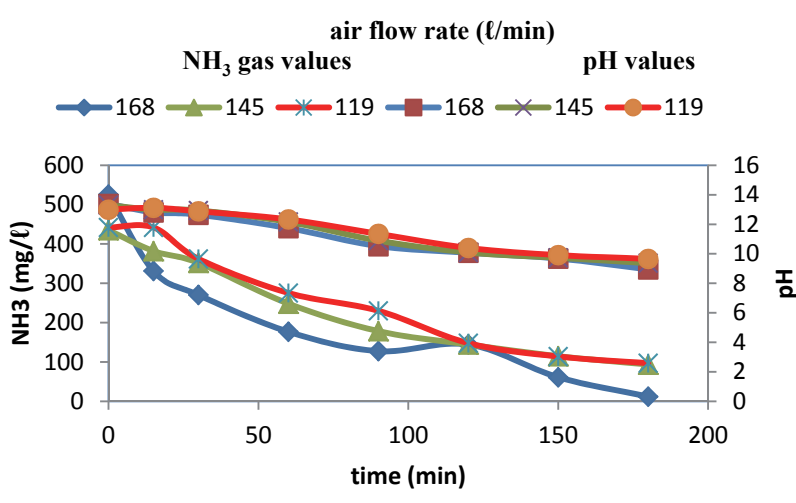

Figure 6

Effect of airflow rate (l/min) for $\mathrm{NH}_{3}$ removal (fully packed material, $\left.500 \mathrm{mg} / \ell \mathrm{NH}_{3}, 25^{\circ} \mathrm{C}\right)$

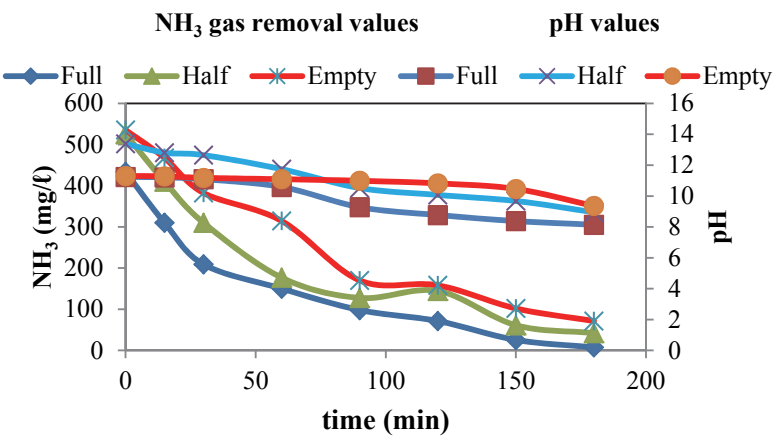

Figure 7

Effect of amount of packing material on $\mathrm{NH}_{3}$ removal $\left(510 \mathrm{mg} / \mathrm{\ell} \mathrm{NH}_{3^{\prime}}\right.$ $168 \mathrm{l} / \mathrm{min}$ air flow rate, $25^{\circ} \mathrm{C}$ )

of the solution. The optimum temperature was $45^{\circ} \mathrm{C}$ and further increases in temperature, resulted in insignificant effects.

\section{Removal of free acid using limestone}

Should the acid in mine-water first be neutralised with $\mathrm{CaCO}_{3}$, it is expected that no addition of lime will be required after $\mathrm{Ba}$ dosing for $\mathrm{NH}_{3}$ removal. Table 3 shows the chemical composition of simulated AMD after adding limestone in the first stage, 


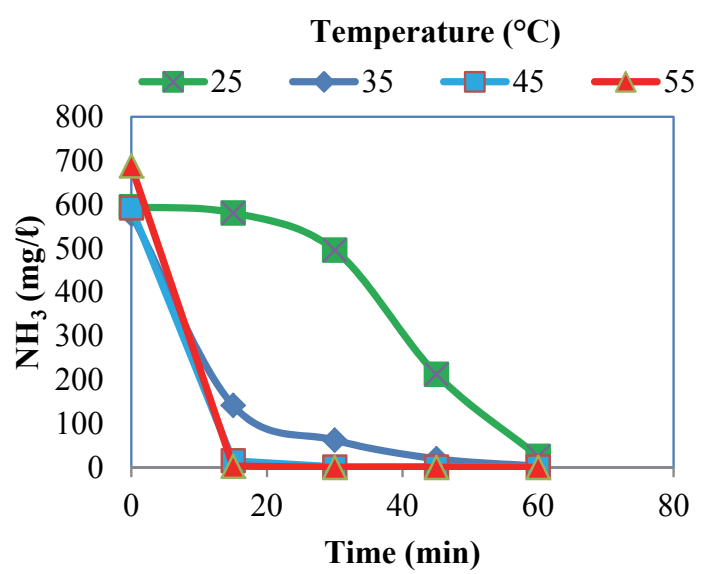

Figure 8

Effect of temperature on the rate of $\mathrm{NH}_{3}$ gas removal in the solution using rotary evaporator $\left(600 \mathrm{mg} / \mathrm{N} \mathrm{NH}_{3^{\prime}}\right)$

followed by various treatment stages. Limestone was added to $\mathrm{pH} 5.5$ to remove the acid. The addition of $\mathrm{NH}_{4} \mathrm{OH}$ resulted in the removal of metals as hydroxides and increases the $\mathrm{pH}$ to 10.5, which was higher than that when limestone was omitted. Limestone was essential because addition of $\mathrm{Ba}(\mathrm{OH})_{2}$ was sufficient to allow all of the $\mathrm{NH}_{3}$ to be removed from the solution. The chemical reactions below show how limestone addition assisted in the elimination of hydrated lime for $\mathrm{NH}_{3}$ removal.

$$
\begin{aligned}
& 2 \mathrm{Fe}^{2+}+2 \mathrm{H}^{+}+2 \mathrm{SO}_{4}^{2-}+\mathrm{CaCO}_{3} \\
& \quad \rightarrow 2 \mathrm{Fe}^{2+}+2 \mathrm{SO}_{4}^{2-}+\mathrm{Ca}^{2+}+\mathrm{HCO}_{3}^{-}+\mathrm{OH}^{-} \\
& 2 \mathrm{Fe}^{2+}+1 / 2 \mathrm{O}_{2}+5 \mathrm{H}_{2} \mathrm{O} \rightarrow 2 \mathrm{Fe}(\mathrm{OH})_{3}+4 \mathrm{H}^{+} \\
& 4 \mathrm{NH}_{4} \mathrm{OH}+4 \mathrm{H}^{+} \rightarrow 4 \mathrm{NH}_{4}^{+}+4 \mathrm{H}_{2} \mathrm{O} \\
& 2 \mathrm{Ba}(\mathrm{OH})_{2}+2 \mathrm{SO}_{4}^{2-}+4 \mathrm{NH}_{4}^{+} \\
& \quad \rightarrow 2 \mathrm{BaSO}_{4}+4 \mathrm{NH}_{3}+4 \mathrm{H}_{2} \mathrm{O}
\end{aligned}
$$

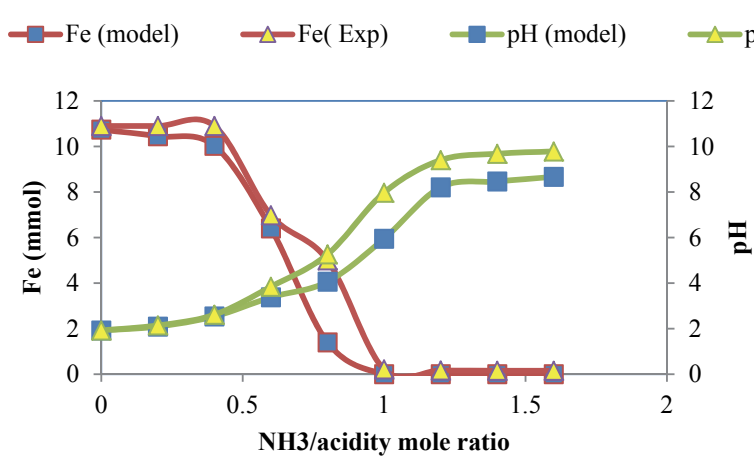

Figure 9

Comparison of the effect of $\mathrm{NH}_{4} \mathrm{OH} /$ acidity on the rate of oxidation $\left(600 \mathrm{mg} / \mathrm{l} \mathrm{Fe}(\mathrm{II}), 2149 \mathrm{mg} / \mathrm{l}\right.$ acidity, $\left.876 \mathrm{mg} / \mathrm{\ell} \mathrm{NH}_{3}, 25^{\circ} \mathrm{C}\right)$

$$
\begin{aligned}
& \mathrm{Ca}^{2+}+\mathrm{HCO}_{3}^{-}+\mathrm{OH}^{-} \rightarrow \mathrm{CaCO}_{3}+\mathrm{H}_{2} \mathrm{O} \\
& 2 \mathrm{Fe}^{2+}+2 \mathrm{H}^{+}+2 \mathrm{SO}_{4}^{2-}+1 / 2 \mathrm{O}_{2}+4 \mathrm{NH}_{4} \mathrm{OH}+2 \mathrm{Ba}(\mathrm{OH})_{2} \\
& \rightarrow 2 \mathrm{Fe}(\mathrm{OH})_{3}+2 \mathrm{BaSO}_{4}+4 \mathrm{NH}_{3}+4 \mathrm{H}_{2} \mathrm{O}
\end{aligned}
$$

\section{Comparison of the experimental results with Visual Minteq model predictions}

Visual Minteq software is used to predict experimental results at equilibrium (Visual MINTEQ, 2010). Figure 9 showed that

\begin{tabular}{|c|c|c|c|c|c|}
\hline \multicolumn{6}{|c|}{$\begin{array}{c}\text { TABLE } 3 \\
\text { Chemical compositions of feed and treated water after limestone was added to simulated acid mine } \\
\text { water }\end{array}$} \\
\hline \multirow[t]{3}{*}{ Parameter } & \multicolumn{5}{|c|}{ Chemical composition } \\
\hline & \multirow[t]{2}{*}{ Feed } & \multicolumn{4}{|c|}{ Treated } \\
\hline & & $\mathrm{CaCO}_{3}$ & $\mathrm{NH}_{4} \mathrm{OH}$ & $\mathrm{Ba}(\mathrm{OH})_{2}$ & $\mathrm{CO}_{2}$ \\
\hline Dosage $(\mathrm{mmol})$ & - & - & 73.7 & 14.4 & - \\
\hline $\mathrm{NH}_{3} /$ acidity $(\mathrm{mol} / \mathrm{mol})$ & & & 1.2 & & \\
\hline Ba dosage $/ \mathrm{SO}_{4}$ removed $(\mathrm{mol} / \mathrm{mol})$ & & & & 0.85 & \\
\hline \multicolumn{6}{|l|}{ Water quality (mmol where applicable) } \\
\hline $\mathrm{pH}$ & 2.95 & 5.5 & 10.5 & 11.1 & 6.5 \\
\hline Acidity $\left(\mathrm{mmol} \mathrm{CaCO}_{3}\right)$ & 12.5 & N/A & N/A & N/A & N/A \\
\hline $\mathrm{Fe}(\mathrm{II})$ & 11.63 & 9.97 & 0.13 & 0.11 & N/A \\
\hline $\mathrm{Ca}$ & 12.0 & 18.35 & 17.66 & 3.21 & $\mathrm{~N} / \mathrm{A}$ \\
\hline $\mathrm{Mg}$ & 11.0 & 11.35 & 12.11 & 1.12 & N/A \\
\hline $\mathrm{Mn}$ & 0.833 & 0.721 & 0.011 & $<\mathrm{DL}$ & $<\mathrm{DL}$ \\
\hline $\mathrm{K}$ & 0.241 & 0.192 & 0.026 & $<\mathrm{DL}$ & $<\mathrm{DL}$ \\
\hline $\mathrm{Cl}$ & 19.18 & 18.82 & 14.2 & 13.2 & 8.20 \\
\hline $\mathrm{SO}_{4}$ & 21.4 & 21.4 & 21.1 & 4.12 & N/A \\
\hline $\mathrm{NH}_{3}$ & $\mathrm{~N} / \mathrm{A}$ & N/A & 60 & 0.2 & N/A \\
\hline
\end{tabular}
the $\mathrm{pH}$ predicted by the model and that established experimentally followed the same pattern. The model predicted optimum $\mathrm{Fe}$ (II) oxidation to occur at a $\mathrm{NH}_{3}$ /acidity mol ratio of unity. Experimentally, the optimum Fe(II) oxidation was found to occur at a mol ratio of 1.2.

\section{CONCLUSIONS}

It was demonstrated using the NB process at laboratory scale, that:

N/A: not assayed

$<$ DL: below detection limit 
- By using $\mathrm{NH}_{4} \mathrm{OH}$ instead of $\mathrm{Ca}(\mathrm{OH})_{2}$, gypsum scaling can be avoided in the full-scale process.

- $\mathrm{NH}_{4} \mathrm{OH}$ precipitated $\mathrm{Fe}$ as the hydroxide in the simulated and real mine-water.

- $\mathrm{Ba}(\mathrm{OH})_{2}$ precipitated $\mathrm{SO}_{4}$ in the mine water as $\mathrm{BaSO}_{4}$ which resulted in partial $\mathrm{NH}_{3}$ removal on account of the raised $\mathrm{pH}$, and the $\mathrm{NH}_{4}^{+}$compound did not precipitate because of the solubility of $\mathrm{NH}_{4} \mathrm{SO}_{4}$

- Hydrated lime treatment resulted in removal of the remaining $\mathrm{NH}_{3}$ by using a rotary evaporator.

- In the treated mine-water, $\mathrm{CO}_{2}$ treatment precipitated $\mathrm{Ca}$ as $\mathrm{CaCO}_{3}$.

- The method was able to remove metal in real and simulated acid mine-water.

- Addition of $\mathrm{CaCO}_{3}$ eliminated the need for addition of hydrated lime and limestone is cheaper than hydrated lime.

- The simulation predictions were similar to the experimental results obtained.

\section{ACKNOWLEDGEMENTS}

Thanks are due to the following organisations: the National Research Foundation, for funding TUT projects on mine-water neutralisation and $\mathrm{SO}_{4}$ removal. Rand Water, for funding the activities of the Rand Water Chair at TUT, and Tshwane University of Technology, which provides substantial financial support for the research programme on mine-water. The inputs of the following people are acknowledged: Professor Fritz Carlsson for editing the document and Mr Luke Gwatidzo (PhD student) for assistance with the laboratory work.

\section{REFERENCES}

APHA (2012) Standard Methods for the Examination of Water and Wastewater (22 $2^{\text {nd }}$ edn.). American Public Health Assoc, New York.

BOLOGO V, MAREE JP and CARLSSON F (2012) Application of magnesium hydroxide and barium hydroxide for the removal of metals and sulphate from mine water (MBO). Water SA 38 (1) 23-28.

HLABELA P (2009) The integrated barium carbonate process for sulphate removal from acid mine water. Ph.D. thesis, North West University.

INAP (INTERNATIONAL NETWORK FOR ACID PREVENTION) (2003) Treatment of sulphates in mine effluents. URL: http://www. inap.com.au/public downloads/Research Projects/Treatment of sulphate in Mine ffluents LoraxReport.pdf $>$ (Accessed 12 April 2012).

JENNINGS SR, NEUMAN DR and BLICKER PS (2008) Acid Mine Drainage and Effects on Fish Health and Ecology: A Review. Reclamation Research Group Publication, Bozeman, MT.

JIMÉNEZ A, AROBA J, DE LA TORRE ML, ANDUJAR JM and GRANDE JA ( 2009) Model of behaviour of conductivity versus $\mathrm{pH}$ in acid mine drainage water, based on fuzzy logic and data mining techniques. J. Hydroinf. 11 (2) 147-153.

KUN LE (1972) A report on the reduction of the sulphate content of acid mine drainage by precipitation with barium carbonate. Internal report, Anglo American Research Laboratories, Project $\mathrm{D} / 3 / \mathrm{W} / 1$.

MAREE JP (2003) Integral Chemical/Biological Process, Republic of South Africa (Patent No. 2003/1362), Australia (Patent No. 2001279996), Canada (Patent No. 2, 418, 472) United States of America (Patent No. 6,863,819), China (Patent 018162053), Great Britain (Patent No. 1,313,668), France (Patent No. 1,313,668), German (Patent No. 1,313,668).

MAREE JP, BOSMAN DJ and JENKINS GR (1989) Chemical removal of sulphate, calcium and heavy metals from mining and power station effluents. Proc. 1st Biennial Conf. of the Water Inst. of Southern Africa, 29-30 March 1989, Cape Town.

MAREE JP, DE BEER M, STRYDOM WF, CHRISTIE ADM and WAANDERS FB (2004) Neutralizing Coal Mine effluent with limestone to decrease metals and sulphate concentrations. Mine Water Environ. 23 81-86.

MINTEQ Visual (2000) URL: http://www2.lwr.kth.se/English/ OurSoftware/vminteq/Visual\% 20MINTEQ tutorial.pdf (Accessed 24 November 2011)

ORVOS M, BALALZ T and BOTH KF (2010) Waste water treatment with ammonia recovery system. J. Civ. Environ. Eng. 2 (2) 113-117.

TRUSLER GE, EDWARDS R I, BROUCKAERT C J and BUCKLEY CA (1988) The chemical removal of sulphates. Proc. $5^{\text {th }}$ National Meeting of the South african Institution of Chemical Engineers, (15-16 August 1988) Pretoria. W3-0-W3-11.

VAN NIEKERK AM and MAREE JP (2001) Coaltech 2010 Colloquium, 2 March 2001, Witbank Civic Theatre, Witbank

SVEHLA G (2011) Vogel's Quantitative Inorganic Analysis (7 ${ }^{\text {th }} \mathrm{edn}$.). John Wiley and Sons, New York. 368 pp.

VOLMAN R (1984) The use of barium sulphide to remove sulphate from industrial effluents. M.Sc. thesis (Chem. Eng.), University of Stellenbosch.

WERNER S and LEE GF (1961) Oxygenation of ferrous iron. Ind. Eng. Chem. 53 (2) 143-146.

ZIEMKIEWICZ PF, SKOUSEN JG, BRANT DL, STERNER PL and LOVETT RJ (1997) Acid mine drainage treatment with armored limestone in an open limestone channel. J. Environ. Qual. 26 $560-569$. 
http://dx.doi.org/10.4314/wsa.v40i3.16 Available on website http://www.wrc.org.za

ISSN 0378-4738 (Print) $=$ Water SA Vol. 40 No. 3 July 2014 ISSN 1816-7950 (On-line) = Water SA Vol. 40 No. 3 July 2014 